\title{
Memory Improvement by Yokukansankachimpihange and Atractylenolide III in the Olfactory Bulbectomized Mice
}

\author{
Hisanao Izumi', Yuzuru Sasaki', Yasushi Yabuki', Yasuharu Shinoda1, Nina Fujita², \\ Satoshi Yomoda' ${ }^{2}$ Kohji Fukunaga ${ }^{1}$ \\ ${ }^{1}$ Department of Pharmacology, Tohoku University Graduate School of Pharmaceutical Sciences, Sendai, Japan \\ ${ }^{2}$ Department of Pharmacology, Kampo Research Laboratories, Kracie Pharma, Ltd., Toyama, Japan \\ Email:kfukunaga@m.tohoku.ac.jp
}

Received 14 March 2016; accepted 3 June 2016; published 6 June 2016

Copyright (C) 2016 by authors and Scientific Research Publishing Inc.

This work is licensed under the Creative Commons Attribution International License (CC BY).

http://creativecommons.org/licenses/by/4.0/

(c) ()) Open Access

\begin{abstract}
Alzheimer's Disease (AD) shows cognitive dysfunction as core symptoms and Behavioral and Psychological Symptoms of Dementia (BPSD). Since acetylcholine nerve system derived from septum is collapsed in the AD patients, we have used Olfactory Bulbectomized (OBX) mice whose cholinergic system is largely impaired in the septum. Recently, Yokukansankachimpihange (YKH), a traditional Japanese Kampo medicine has used for BPSD in addition to improve cognitive dysfunction in AD patients. However the essential components for cognition and BPSD improvement and their mechanism are largely unknown. In present study, we found that Atractylenolide III (Aen-III), one of the components of YKH, improved cognitive deficits and depression in the OBX mice. OBX mice were orally administered with Aen-III (1.0 and $3.0 \mathrm{mg} / \mathrm{kg})$ and YKH extracts daily for 18 days. Like YKH extracts, the Aen-III treatments ameliorated cognitive deficits and depression-like behavior observed in OBX mice. Importantly, Aen-III administration significantly restored the decreases in $\mathrm{Ca}^{2+} /$ calmodulin-dependent protein kinase II (CaMKII) autophosphorylation and phosphorylation of $\mathrm{Ca}^{2+} /$ calmodulin-dependent protein kinase IV (CaMKIV) and cyclic AMP response element binding protein (CREB). The restoration of CaMKII and CaMKIV signaling is closely related to the increased BDNF levels. Furthermore, ATP reduction in OBX mice was rescued by Aen-III (3.0 $\mathrm{mg} / \mathrm{kg})$ and YKH $(1000 \mathrm{mg} / \mathrm{kg})$ treatment. In summary, Aen-III as a component of YKH ameliorates cognitive dysfunctions and depression via restoring CaMKII and CaMKIV signaling.
\end{abstract}

\section{Keywords}

Yokukansankachimpihange, Atractylenolide III, Olfactory Bulbectomized Mice, CaMKII, BDNF 


\section{Introduction}

Alzheimer's Disease (AD) is a progressive neurodegenerative disorder that causes cognitive impairment as core symptoms and depression and aggressive-like behaviors as Behavioral and Psychological Symptoms of Dementia (BPSD) [1]. In AD patients, the downregulation of acetylcholine neurons is the causative pathology in the Central Nervous System (CNS), which is confirmed by improvement of clinical symptoms by treatments of acetylcholinesterase inhibitors, such as donepezil and rivastigmine [2]. It has been reported that AD patients have theolfactory system impairment [3]-[6]. The olfactory bulb is innervated by acetylcholine nerve from the septum, and Olfactory Bulbectomy (OBX) causes the retrograde nerve injury of the septal cholinergic neurons [7]. Therefore, the acetylcholine nerve projections to cerebral cortex and hippocampus from the septum are also impaired, thereby causing cognitive impairment [8] [9] and depression [10]. We have used the OBX mice as AD model to verify the improvement of cognition and BPSD by AD drugs [11] [12].

Yokukansankachimpihange (YKH), traditional Japanese herbal medicine (also Kampo medicine), is used traditionally for treatment of neurasthenia, hysteria, insomnia, menopausal neurosis, and pediatric epilepsy [13]. YKH is consists of Atractylodis rhizome, Japanese angelica root, Bupleurum root, Citrus unshiu peel, Cnidium rhizome, Glycyrrhiza, Poriasclerotium, Pinellia tuber, and Uncaria hook. Recently Yokukansan also has a clinical efficacy against BPSD in Alzheimer's disease patients [14] and in cerebrovascular dementia model rat [15]. Likewise, YKH improves the memory dysfunction a core symptom of AD in this rat [16]. Recently, atractylenolide III (Aen-III), component of Byaku-jutsu (Atractylodis rhizome), has been reported to have effect of improving learning and memory dysfunction following chronic high-dose homocysteine administration in rat [17]. Aen-III exerts the effect by enhancing phosphorylation of the PKC and inhibiting the ROS levels and caspase-3 activity, suggesting that Aen-III may have therapeutic potential to the cognitive dysfunction.

Therefore, we here investigated whether oral administration of Aen-III improves the cognitive impairment and depression in OBX mice. We also clarify the mechanisms underlying cognitive improvement in OBX.

\section{Materials and Methods}

\subsection{Animal}

Adult male DDY mice of 8 weeks were purchased from Nippon SLC (Hamamatsu, Japan) and housed in cages under the conditions of constant temperature $\left(23^{\circ} \mathrm{C} \pm 1{ }^{\circ} \mathrm{C}\right)$ and humidity $(55 \% \pm 5 \%)$ with a 12-h light/dark cycle (light; 09:00-21:00 h), and could freely access to food and water. All experimental procedures using animals were approved by the Committee on Animal Experiments at Tohoku University.

\subsection{Operation and Drug Treatment Diagram}

OBX mice were prepared as described previously [7] [8]. After a two-week recovery period, drugs were administered once a day for 18 days, and then mice were subjected to behavioral tests and subsequently dissected as shown in Figure 1. To obtain YKH powder, Atractylodis rhizome 4 g, Japanese angelica root 3 g, Bupleurum root 2 g, Citrus unshiu peel 3 g, Cnidiumrhizome 3 g, Glycyrrhiza 1.5 g, Poria sclerotium 4 g, Pinellia tuber 5 g and Uncaria hook $3 \mathrm{~g}$ were mixed and extracted with hot water, and then spray-dried to obtain $5 \mathrm{~g}$ of $\mathrm{YKH}$

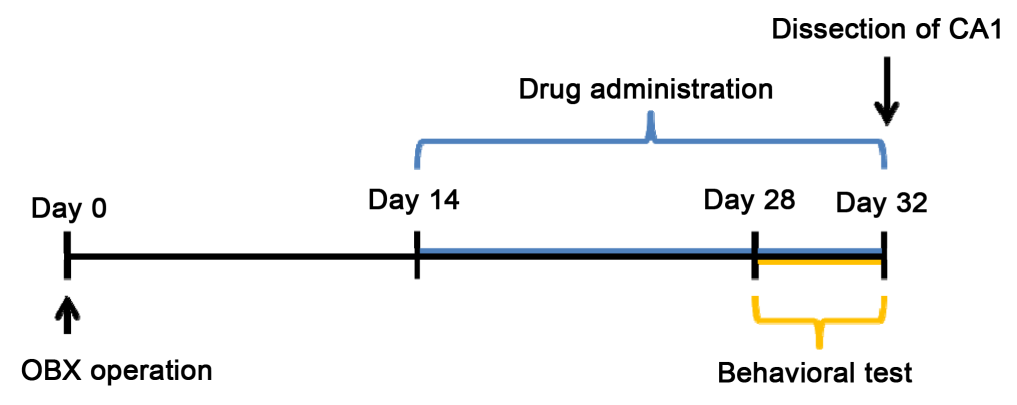

Figure 1. Experimental protocol. Two weeks after OBX operation, drugs were administered once a day for 18 days. From day 28, mice were subjected to behavioral tests. At day 32, finishing behavioral tests, mice were sacrificed and the hippocampal CA1 region was dissected for Western blotting. 
powder extract. Aen-III (Wako, Osaka, Japan) was dissolved in Corn oil (Wako, Osaka, Japan) and administered orally at two doses (1.0 and $3.0 \mathrm{mg} / \mathrm{kg}$ in a volume of $0.5 \mathrm{~mL} / 100 \mathrm{~g}$ body weight).YKH was suspended in $0.5 \%$ carboxymethyl cellulose (CMC) and administered orally at $1000 \mathrm{mg} / \mathrm{kg}$ in a volume of $0.5 \mathrm{~mL} / 100 \mathrm{~g}$ body weights. Administration of YKH at $1000 \mathrm{mg} / \mathrm{kg}$ is equal to $130 \mu \mathrm{g} / \mathrm{kg}$ of Aen-III. Sham-operated mice were treated with the same volume of suspended solution.

\subsection{Y-Maze Task}

Short-term spatial reference memory and attentions were evaluated by the spontaneous alternation behavior in a Y-maze as described [18]. The apparatus consisted of three identical arms (50 cm long, $16 \mathrm{~cm}$ wide, $32 \mathrm{~cm}$ high) made from black plexiglas. Each mouse was placed on the edge of one arm and allowed to move freely through the maze during an 8-min session. An alternation was defined as entries into all three arms on consecutive choices. The number of maximum alternations was defined as the total number of arms entries minus two, and the percentage of alternation was calculated as actual alternation/maximum alternations $\times 100$. In addition, the total number of arms entries during the session was also determined as an indicator of locomotion activity.

\subsection{Novel Object Recognition Task}

Long-term and cognitive memory was evaluated by novel object recognition task. Mice were individually habituated an open-field box $(35 \mathrm{~cm} \times 25 \mathrm{~cm} \times 35 \mathrm{~cm}$ ) for 2 consecutive days. The experimenter scoring behavior was blinded to the treatment. The novel task was assessed as described [18]. In the acquisition phase, two objects of the same material ware placed in the test chamber and mice were allowed to explore them for 10 min. After $24 \mathrm{~h}$, one of the objects was replaced by novel object and mice were allowed to explore for $5 \mathrm{~min}$. The exploratory behavior was analyzed. After each session, objects were thoroughly cleaned with $75 \%$ ethanol to prevent odor recognition. Exploration of an object was defined as rearing on the object or sniffing it at a distance of less than $1 \mathrm{~cm}$, touching it with the nose, or both. Discrimination of spatial novelty was assessed by comparing the difference between exploratory contacts to familiar and novel objects and the total number of contacts, which made it possible to adjust for difference in total exploratory contacts.

\subsection{Step-Through Passive Avoidance Task}

The step-through passive avoidance task is a paradigm to evaluate long-term memory was assessed as described [18]. Training and retention trials of the passive avoidance task were conducted in a box consisting of dark (25 $\times$ $25 \times 25 \mathrm{~cm})$ and light $(14 \times 10 \times 25 \mathrm{~cm})$ compartments and a floor of stainless steel rods. Floor rods in the dark compartment were connected to an electronic stimulator (Nihon Kohden, Tokyo, Japan). Mice were habituated to the apparatus the day before passive avoidance acquisition. In the training trial, mice were placed in the light compartment. Entering the dark compartment, the door was closed and an electric shock ( $0.3 \mathrm{~mA}, 2 \mathrm{sec})$ was delivered to grid floor and mice were removed from the apparatus $30 \mathrm{~s}$ later. In the testing trial, $24 \mathrm{~h}$ later, mice were placed in the light compartment and step-through latency was recorded until $300 \mathrm{sec}$ had elapsed to assess retention level.

\subsection{Tail Suspension Task}

In the tail suspension task, duration of immobility time was measured according to the method described by Steru et al. [19]. In this test, mice were suspended $50 \mathrm{~cm}$ above the floor via attachment to a tail hanger with adhesive tape. Immobility time was recorded during a $10 \mathrm{~min}$. Mice were considered immobile only when they hung passively and remained completely motionless.

\subsection{Western Blotting Analyses}

After decapitation of animals, the brain was removed and tissues from the dorsal hippocampal CA1 region were dissected, frozen in liquid nitrogen and stored at $-80^{\circ} \mathrm{C}$. For western blotting assay, frozen tissues were homogenized in $150 \mu \mathrm{L}$ buffer containing $50 \mathrm{mM}$ Tris-HCl, pH 7.4, 0.5\% Triton X-100, 4 mM EGTA, $10 \mathrm{mM}$ EDTA, $1 \mathrm{mM} \mathrm{Na}_{3} \mathrm{VO}_{4}, 40 \mathrm{mM}$ sodium pyrophosphate, $50 \mathrm{mM} \mathrm{NaF}, 100 \mathrm{nM}$ calyculin A, $50 \mu \mathrm{g} / \mathrm{ml}$ leupeptin, $25 \mu \mathrm{g} / \mathrm{ml}$ pepstatin A, $50 \mu \mathrm{g} / \mathrm{ml}$ trypsin inhibitor, and $1 \mathrm{mM}$ dithiothreitol. Insoluble material was removed by a $10 \mathrm{~min}$ 
centrifugation at 20,400 g. Protein concentration was determined using Bradford's assay, samples were boiled 3 min in Laemmli's sample buffer, and equivalent amounts of protein were electrophoresed on Sodium Dodecyl Sulfate (SDS)—polyacrylamide gels and transferred to an Immobilon polyvinylidene diflouride membrane for 2 $\mathrm{h}$ at $70 \mathrm{~V}$. After blocking with Tris with Tween 20 Buffered-Saline (TTBS) solution (50 mM Tris- $\mathrm{HCl}, \mathrm{pH} 7.5$, $150 \mathrm{mM} \mathrm{NaCl}, 0.1 \%$ Tween20) containing 5\% fat-free milk powder for $1 \mathrm{~h}$ at room temperature, membranes were incubated overnight at $4^{\circ} \mathrm{C}$ using the following antibodies: Anti-phospho-CaMKII (1:5000; [20]), antiCaMKII (1:5000; [20]), anti-phospho-CaMKIV (Thr196) (1:1000; Santa Cruz Biotechnology), anti-CaMKIV (1:1000; Santa Cruz Biotechnology), anti-phospho-CREB (Ser133) (1:1000; Millipore), anti-CREB (1:1000; Millipore), anti-BDNF (1:500; Santa Cruz Biotechnology), anti- $\beta$-tubulin (1:5000; Sigma-Aldrich). Since individual total and phosphorylated protein antibodies were labeled at the same molecular weight and produced by immunizing the same animals, different membranes, which the same samples and equivalent amounts of protein were electrophoresed and transferred, were incubated with respective antibodies. We confirmed that the same amounts of protein were transferred to membrane by quantifications of $\beta$-tubulin. After washing, membranes were incubated with the appropriate horseradish peroxidase-conjugated secondary antibody diluted in TTBS solution for $60 \mathrm{~min}$ at room temperature. Blots were developedusing an ECL immunoblotting detection system (Amersham Biosciences) and visualized on X-ray film (Fuji Film, Tokyo, Japan). Autoradiographic films were scanned for densitometry analysis (Lasergraphics, Irvine, CA, USA) and quantitated using Image Gauge version 3.41 (Fuji Film).

\subsection{ATP Assay}

Hippocampal regions were dissected out and rapidly frozen in liquid nitrogen and stored at $-80^{\circ} \mathrm{C}$ until using. ATP contents in the hippocampal extracts were measures using the ATP assay kit (Toyo Ink, Tokyo, Japan) according to the manufacturer's protocol. In brief, frozen hippocampal samples were homogenized in the homogenate buffer (0.25 M sucrose, $10 \mathrm{mM}$ HEPES-NaOH, pH 7.4), and centrifuged at $1000 \mathrm{~g}$ for $10 \mathrm{~min}$ at $4{ }^{\circ} \mathrm{C}$. The supernatant was collected and mixed with the extraction buffer at room temperature, and 30 min later, luciferin buffer was added to each sample. Oxyluciferin was detected using a luminometer (Gene Light 55, Microtec, Funabashi, Japan).

\subsection{Statistical Evaluation}

All values in graphs are expressed as mean \pm SEM. Significant differences among groups were determined using one-way analysis of variance (ANOVA) followed by Dunnett's test for all experiments. $\mathrm{p}<0.05$ represented a statistically significant difference.

\section{Results}

\subsection{YKH and Aen-III Administration Ameliorates Cognitive Deficits and Depression-Like Behavior in OBX Mice}

We first asked whether YKH and Aen-III administration improve the memory dysfunction and depression observed in OBX mice. In Y-mazetask, the percentage of alternations significantly decreased in vehicle-treated OBX mice compared with sham-operated mice (sham control: 73.9\% $\pm 2.0 \%, \mathrm{n}=5$; OBX: 48.9\% $\pm 4.9 \%, \mathrm{n}=7$ ) without changes in the total number of arm entries (Figure 2(a) and Figure 2(b)). Oral administration of YKH $1000 \mathrm{mg} / \mathrm{kg}$ and Aen-III 1.0, $3.0 \mathrm{mg} / \mathrm{kg}$ in OBX mice significantly improved the percentage of alternation compared to vehicle-treated OBX mice (OBX YKH: 69.6\% \pm 1.7\%, $\mathrm{n}=8$; OBX Aen-III $1.0 \mathrm{mg} / \mathrm{kg}: 66.4 \% \pm 3.9 \%$, $\mathrm{n}=8$; OBX Aen-III 3.0 mg/kg: 75.5\% + 4.5\%, $\mathrm{n}=8$ ) (Figure 2(b)).

We also performed novel object recognition task to assess the cognitive function [21]. In a training session, there were no significant differences in discrimination index among the groups (Figure 2(c)). After $24 \mathrm{~h}$ retention interval between trial and test sessions, the vehicle-treated OBX mice failed to discriminate between the familiar and novel objects (Figure 2(d)). Under the same condition, the decreased discrimination index in OBX mice was significantly restored by administration Aen-III (1.0, 3.0 mg/kg) and YKH (1000 mg/kg) (Figure 2(d)).

We assessed contextual memory by step-through passive avoidance task. In vehicle-treated OBX mice, the latency to enter a dark room was significantly decreased relative to sham-operated mice (sham control: $300 \pm 0 \mathrm{~s}$, 


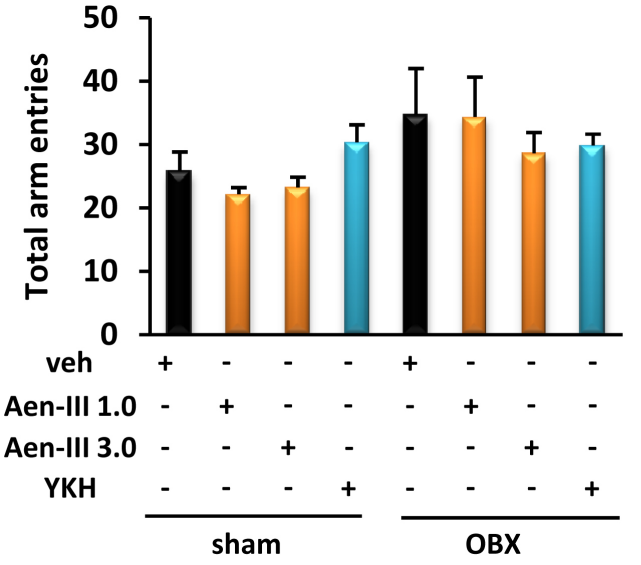

(a)

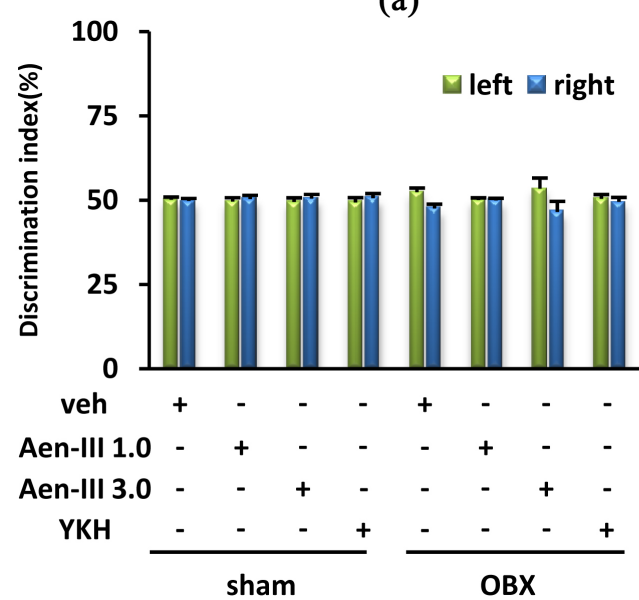

(c)

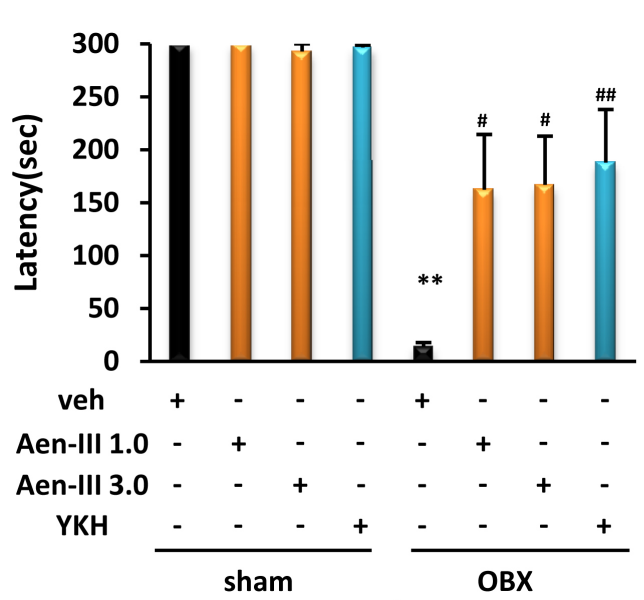

(e)

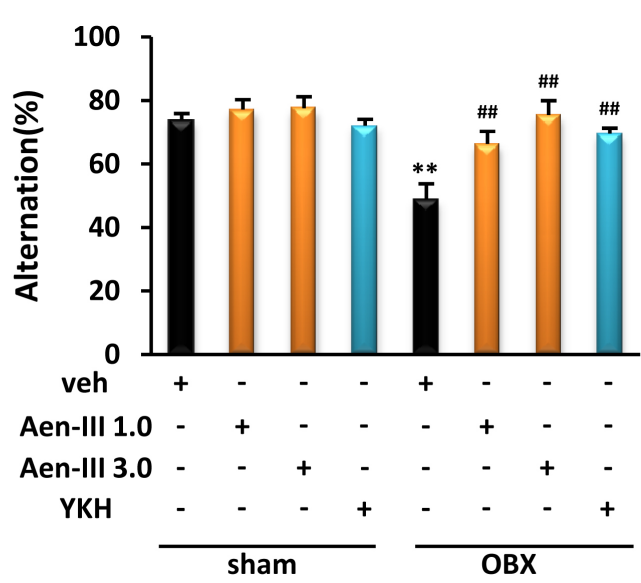

(b)

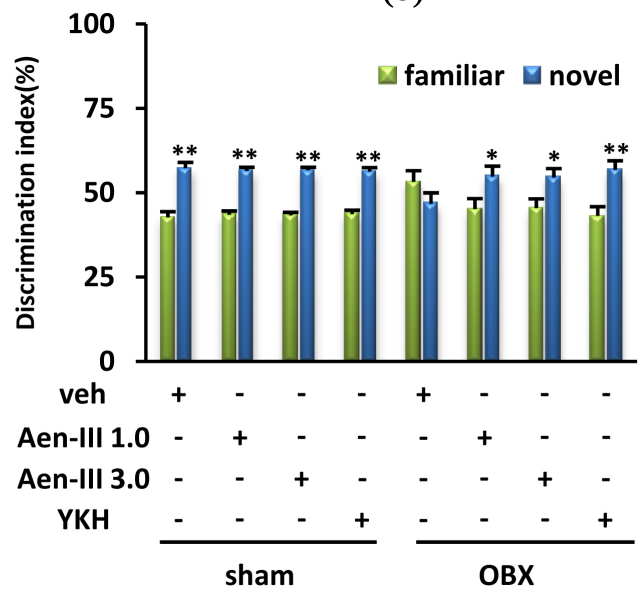

(d)

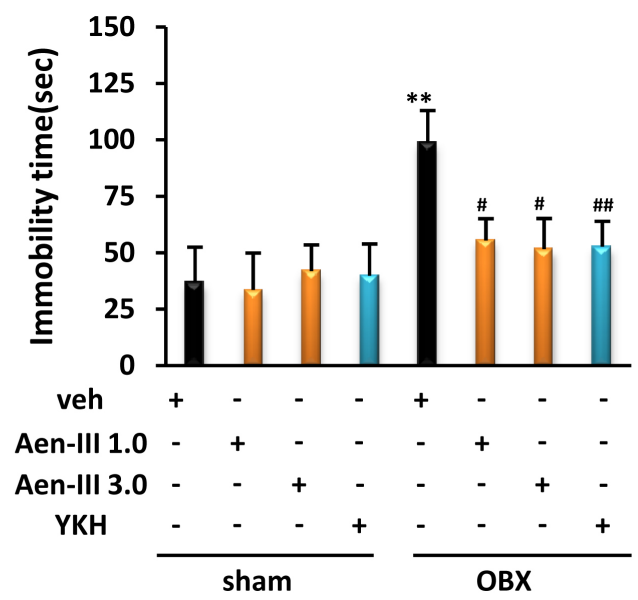

(f)

Figure 2. Administration of YKH and Aen-III improves cognitive deficits and depression-like behavior in OBX mice. (a) In a Y-maze task, there were no differences in total number of arms entries among all groups; (b) Alternation in a Y-maze task was measured 14 days after OBX operation; (c) The discrimination index (\%) was measured 15 days after OBX operation in a trial session; (d) The discrimination index (\%) in a test session was determined 16 days after OBX operation, $24 \mathrm{~h}$ after trial session; (e) Latency time in step-through passive avoidance task was measured 16, 17 days after OBX operation; (f) Immobility time in tail suspension task was measured at 18 days after OBX operation. Each bar represents the mean \pm S.E.M. $\left({ }^{*} \mathrm{p}<0.05,{ }^{* *} \mathrm{p}<0.01\right.$ vs. sham-operated mice, ${ }^{\#} \mathrm{p}<0.05,{ }^{\#} \mathrm{p}<0.01$ vs. OBX mice). 
$\mathrm{n}=5$; OBX: $14.0 \pm 3.9 \mathrm{~s}, \mathrm{n}=7$ ) (Figure 2(e)). YKH $1000 \mathrm{mg} / \mathrm{kg}$ and Aen-III 1.0, $3.0 \mathrm{mg} / \mathrm{kg}$ administration significantly improved the decreased latency in OBX mice (OBX YKH: $187.9 \pm 50.1 \mathrm{~s}, \mathrm{n}=8$; OBX Aen-III 1.0 mg/kg: $162.3 \pm 52.2 \mathrm{~s}, \mathrm{n}=8$; OBX Aen-III $3.0 \mathrm{mg} / \mathrm{kg}$ : $166.9 \pm 46.0 \mathrm{~s}, \mathrm{n}=8$ ) (Figure 2(e)).

Finally, we assessed the improvement of BPSD-like behavior such as depression. In tail suspension task, the immobility time significantly increase in vehicle treated OBX mice, and which was significantly improved by treatment with YKH $(1000 \mathrm{mg} / \mathrm{kg}$ ) and Aen-III $(1.0$ and $3.0 \mathrm{mg} / \mathrm{kg}$ ) (sham control: $37.0 \pm 15.5 \mathrm{~s}, \mathrm{n}=11$; OBX: $98.9 \pm 14.1 \mathrm{~s}, \mathrm{n}=14$; OBX YKH: $52.7 \pm 11.2 \mathrm{~s}, \mathrm{n}=16$; OBX Aen-III $1.0 \mathrm{mg} / \mathrm{kg}$ : $55.5 \pm 9.6 \mathrm{~s}, \mathrm{n}=15$; OBX Aen-III 3.0 mg/kg: $51.6 \pm 13.6 \mathrm{~s}, \mathrm{n}=8$ ) (Figure 2(f)).

These results show that YKH and Aen-III have the equal efficacy to improve the cognitive deficits and depression-like behavior observed in OBXmice.

\subsection{Administration YKH and Aen-III Improves CaMKII Autophosphorylation and CaMKIV/CREB Signaling}

Since we previously confirmed that the decreased CaMKII autophosphorylation in the hippocampal CA1 region is closely associated with memory deficits in OBX mice [11]. CaMKIV activity was essential for improve the depression-like behaviors by anti-depressants [22]. Therefore, we investigated whether Aen-IIIor YKH treatment ameliorates CaMKII autophosphorylation and CaMKIV/CREB phosphorylation in hippocampal CA1 region. Indeed, CaMKII autophosphorylation (Thr-286) significantly decreased in vehicle-treated OBX mice (sham control: 100\% $\pm 3.5 \%, \mathrm{n}=8$; OBX: 61.7\% $\pm 4.8 \%, \mathrm{n}=8$ ) (Figure 3(a) and Figure 3(b)). The administration of YKH $(1000 \mathrm{mg} / \mathrm{kg})$ and Aen-III $(1.0,3.0 \mathrm{mg} / \mathrm{kg})$ significantly restored the decreased CaMKII autophosphorylation (OBX YKH: $105.6 \% \pm 5.7 \%, \mathrm{n}=8$; OBX Aen-III $1.0 \mathrm{mg} / \mathrm{kg}: 96.1 \% \pm 8.0 \%, \mathrm{n}=8$; OBX Aen-III $3.0 \mathrm{mg} / \mathrm{kg}: 100.4 \% \pm 3.0 \%, \mathrm{n}=8$ ) (Figure 3(a) and Figure 3(b)).

Additionally, we previously documented that CaMKIV and CREB phosphorylation drastically decreased in OBX mice [11] [23]. We next examined the effects of YKH and Aen-III for CaMKIV/CREB signaling. We observed the significantly decrease of CaMKIV phosphorylation (Thr-196) (sham control: $100 \% \pm 5.3 \%, \mathrm{n}=8$; OBX: $44.7 \% \pm 6.7 \%, n=8$ ), CREB phosphorylation (Ser-133) (sham control: $100 \% \pm 4.3 \%, n=8$; OBX: $62.3 \% \pm 3.7 \%, \mathrm{n}=8$ ) in hippocampal CA1 region of vehicle treated OBX mice (Figure 3(a) and Figure 3(b)). The decreased CaMKIV (OBX YKH: 89.4\% \pm 6.6\%, $\mathrm{n}=8$; OBX Aen-III $1.0 \mathrm{mg} / \mathrm{kg}$ : 90.1\% $\pm 12.2 \%, \mathrm{n}=8$; OBX Aen-III 3.0 mg/kg: 96.2\% \pm 9.7\%, $\mathrm{n}=8$ ) and CREB (OBX YKH: 95.2\% $\pm 3.8 \%, \mathrm{n}=8$; OBX Aen-III 1.0 $\mathrm{mg} / \mathrm{kg}: 94.6 \% \pm 4.3 \%, \mathrm{n}=8$; OBX Aen-III $3.0 \mathrm{mg} / \mathrm{kg}: 81.4 \% \pm 4.0 \%, \mathrm{n}=8$ ) phosphorylation significantly ameliorated by YKH $1000 \mathrm{mg} / \mathrm{kg}$ and Aen-III 1.0, $3.0 \mathrm{mg} / \mathrm{kg}$ administration (Figure 3(a) and Figure 3(b)).

Since CaMKIV/CREB signaling is essential for the elevation of BDNF levels in OBX rats [24] [25], we evaluated the BDNF levels in the CA1 regions. The BDNF levels significantly decreased in vehicle treated OBX mice (sham control: $100 \% \pm 2.8 \%, \mathrm{n}=8$; OBX: $49.8 \% \pm 5.2 \%, \mathrm{n}=8$ ). The reduced BDNF levels were rescued by YKH and Aen-III administration (OBX YKH: $97.3 \% \pm 15.2 \%, \mathrm{n}=8$; OBX Aen-III $1.0 \mathrm{mg} / \mathrm{kg}$ : $108.3 \% \pm$ 8.1\%, $\mathrm{n}=8$; OBX Aen-III $3.0 \mathrm{mg} / \mathrm{kg}: 89.4 \% \pm 6.9 \%, \mathrm{n}=8$ ) (Figure 3(a) and Figure 3(b)). Taken together, the improving effect of YKH and Aen-III for behavioral deficit in OBX mice is exerted through the restoration of above signals.

\subsection{Administration of Aen-III and YKH Restored Reduced ATP Levels in OBX Mouse Hippocampus}

Since it has been reported that ATP levels are decreased in AD model mouse brain [26], we investigated the ATP levels in the hippocampus of OBX mice. As expected, the ATP levels significantly reduced in OBX mice, which was rescued by YKH, and Aen-III (3.0 mg/kg) treatment (sham control: 100\% $\pm 3.1 \%, \mathrm{n}=10$; OBX: 68.4\% $\pm 4.1 \%, \mathrm{n}=14$; OBX YKH: $86.4 \% \pm 2.4 \%, \mathrm{n}=10$; OBX ARM: $97.3 \% \pm 2.8 \%, \mathrm{n}=10$; OBX Aen-III $3.0 \mathrm{mg} / \mathrm{kg}$ : $86.8 \% \pm 4.8 \%, \mathrm{n}=10$ ) (Figure 4).

\section{Discussion}

The improvement of memory and BPSD-like behaviors with yokukansan (YKS) has been reported in OBX mice [27] and amyloid precursor protein transgenic mice [28]. However, the essential components of YKS and its mechanism to elucidate the improvement have not been defined. Since Aen-III, a component of Byaku-jutsu 


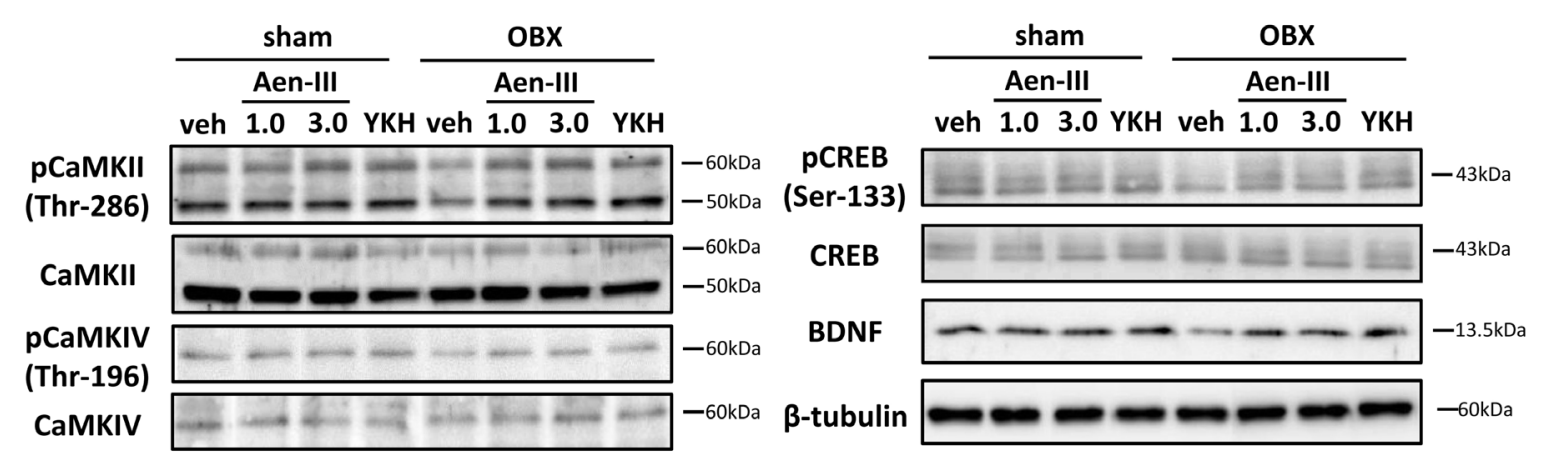

(a)
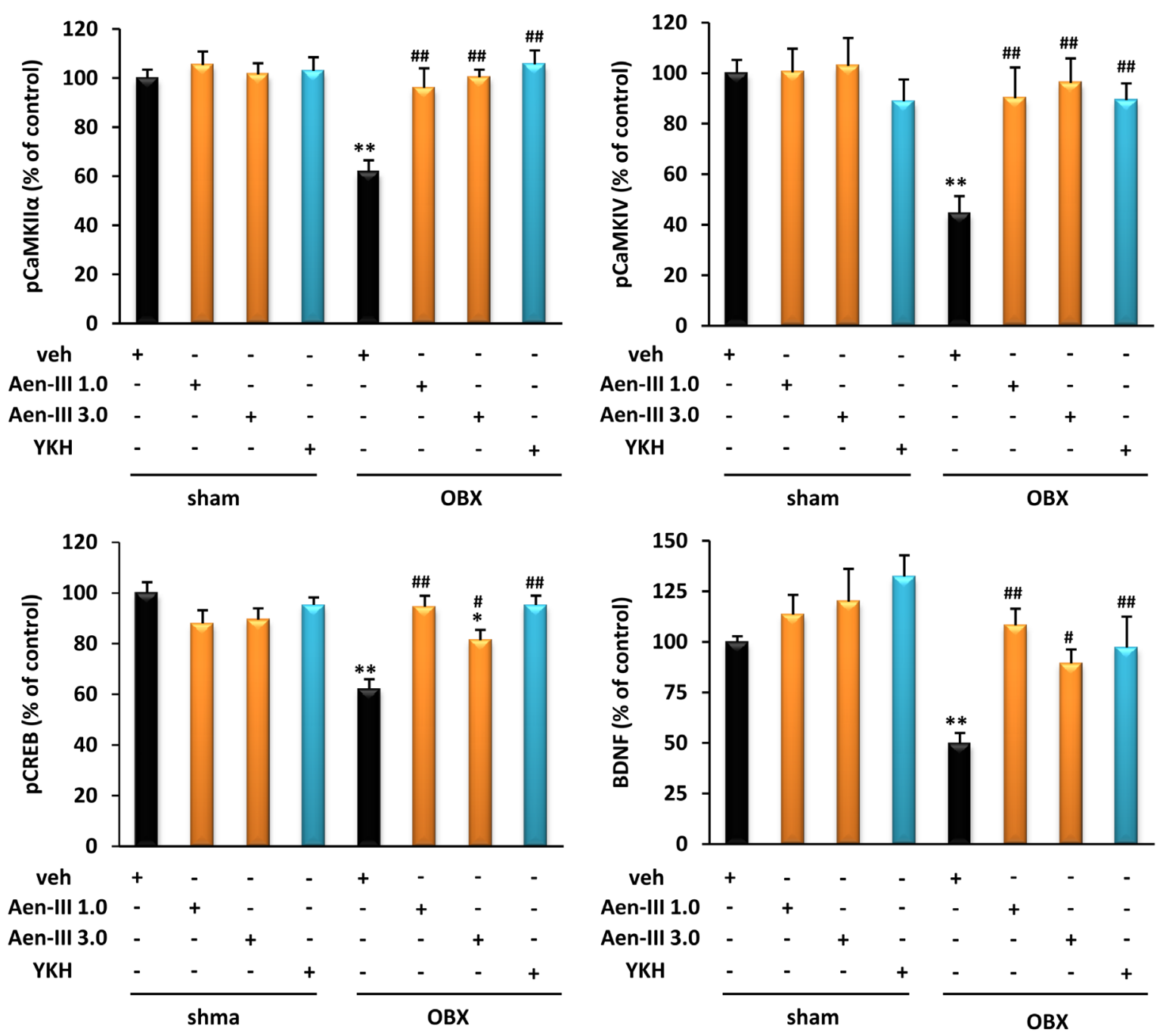

(b)

Figure 3. YKH and Aen-III treatment rescues decreased CaMKII autophosphorylation and CaMKIV/CREB signaling in OBX mice. (a) Representative images of western blots of hippocampal CA1 region using antibodies against autophosphorylated CaMKII (Thr-286), CaMKII, phosphorylated CaMKIV (Thr-196), CaMKIV, phosphorylated CREB (Ser-133), CREB, BDNF, and $\beta$-tubulin; (b) Quantification of autophosphorylated CaMKII, phosphorylated CaMKIV, phosphorylated CREB and BDNF. Data are showed as percent of sham-operated mice. Each bar represents the mean \pm S.E.M. $\left({ }^{*} \mathrm{p}<0.05,{ }^{* *} \mathrm{p}<0.01\right.$ vs. sham-operated mice, ${ }^{\#} \mathrm{p}<0.05,{ }^{\#} \mathrm{p}<0.01$ vs. OBX mice). 


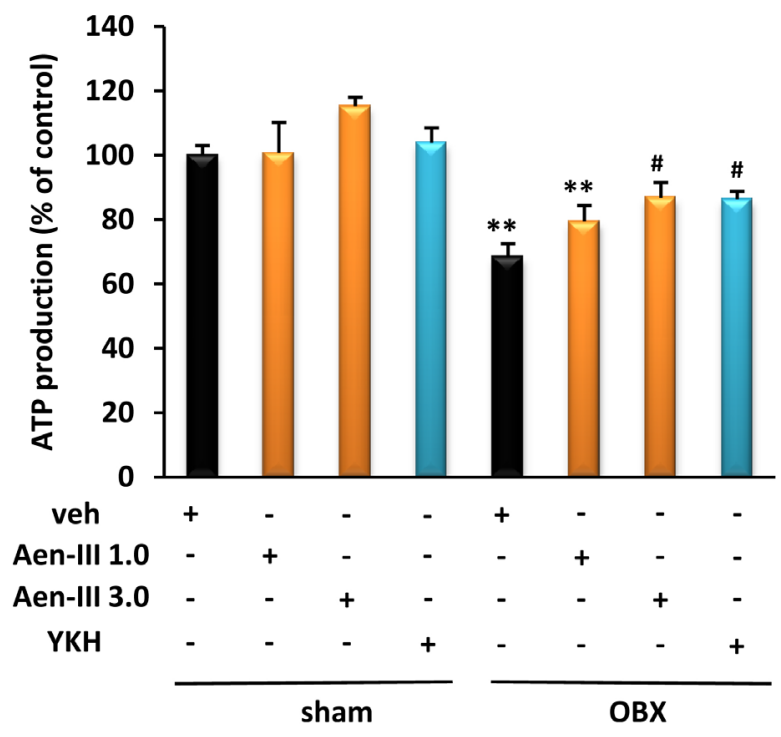

Figure 4. Quantitative analysis of ATP concentration in the hippocampus. The decreased ATP levels were restored by YKH and Aen-III administration in OBX mice. Data are showed as percent of sham-operated mice. Each bar represents the mean \pm S.E.M. ( ${ }^{* *} \mathrm{p}<0.01$ vs. sham-operated mice, ${ }^{\#} \mathrm{p}<0.05,{ }^{\# \#} \mathrm{p}<0.01$ vs. OBX mice).

(Atractylodis rhizome), has been reported to have effect of improving learning and memory dysfunction following chronic high-dose homocysteine administration in rat [16], we focused effects of Aen-III to elucidate the mechanism underling memory improvement in the present study. In addition, we tried to get proof-of-concept to improve memory by YKH, another Kampo medicine in animal studies, because it now popular to treat BPSDlike behaviors in human.

As expected, like YKH, Aen-III ameliorated memory deficits and depression behaviors observed in OBX mice. In addition, the previous study focused on PKC activation by Aen-III to reduce the oxidative stress and apoptosis [16]. We here investigated CaMKII and CaMKIV/CREB signaling to elucidate the mechanisms underling improvement of memory and depression behaviors. CaMKII autophosphorylation is essential for longterm potentiation (LTP) induction in the hippocampal CA1 region [29] and memory formation [30]. Indeed, CaMKII autophosphorylation significantly decreased and LTP was impaired in OBX mice [11]. As expected, Aen-III or YKH treatment significantly ameliorated the reduced CaMKII autophosphorylation in hippocampal CA1 region. Additionally, CaMKIV and CREB phosphorylation decreased in OBX mice were also significantly restored by Aen-III or YKH treatment. Furthermore, CaMKIV/CREB downstream target, BDNF has been known to mediate the antidepressant effects of selective serotonin reuptake inhibitors (SSRI) [31]-[34]. We previously observed the reduction of phosphorylated CaMKIV, CREB and BDNF levels in OBX mice [11]. In addition, since the hippocampal LTP is impaired in mice lacking the BDNF gene, BDNF is closely involved in the hippocampus-mediated learning and memory [35] [36]. In addition, BDNF treatment of the hippocampal slices of BDNF knockout mice rescues deficits in LTP and synaptic transmission [37]. In AD patients, BDNF expression is severely decreased in the hippocampus and cortex [38] [39]. Taken together, BDNF is considered to be important in the pathogenesis of $\mathrm{AD}$. In this context, the observation that improvement of CaMKIV-CREBBDNF signaling with YKH and Aen-III is critical for not only improvement of memory but also rescue of depression behaviors in AD patients. Furthermore, YKH and Aen-III restored the ATP levels in OBX mouse hippocampus. ATP is key regulator for energy production in the brain. YKH and Aen-III are likely to have potency of brain metabolism enhancement.

\section{Conclusion}

Taken together, this study showed the first evidence for the improvement effects of Aen-III in cognitive deficits 
as core symptoms of AD and depression as BPSD in AD model mice. Aen-III ameliorated behavioral dysfunction through restoring the decreased CaMKII autophosphorylation and CaMKIV-CREB-BDNF signaling. Moreover, Aen-III has ability to enhance the ATP levels. Thus, our study shows the potential of Aen-III for AD therapy.

\section{Acknowledgements}

This work was supported in part by grants from the Ministry of Education, Culture, Sports, Science and Technology, Japan (KAKENHI 25293124, KF) and Smoking Research Foundation (KF).

\section{Conflicts of Interest}

The authors declare that we have no conflicts of interest to disclose.

\section{References}

[1] Finkel, S., Silva, J.C.E., Cohen, G., Miller, S. and Sartorius, N. (1996) Behavioral and Psychological Signs and Symptom of Dementia: A Consensus Statement on Current Knowledge and Implications for Research and Treatment. International Psychogeriatrics, 8, 497-500. http://dx.doi.org/10.1017/S1041610297003943

[2] Giacobini, E. (2000) Cholinesterase Inhibitor Therapy Stabilizes Symptoms of Alzheimer's Disease. Alzheimer Disease and Associated Disorders, 14, S3-S10. http://dx.doi.org/10.1097/00002093-200000001-00002

[3] Corwin, J., Serby, M., Conrad, P. and Rotrosen, J. (1985) Olfactory Recognition Deficit in Alzheimer's Disease and Parkinsonian Dementia. IRCS Journal of Medical Science, 13, 260.

[4] Koss, E. (1986) Olfactory Dysfunction in Alzheimer’s Disease. Developmental Neuropsychology, 2, 89-99. http://dx.doi.org/10.1080/87565648609540332

[5] Kovacs, T., Cairns, N.J. and Lantos, P.L. (2001) Olfactory Centers in Alzheimer's Disease: Olfactory Bulb Is Involved in Early Braak’s Stage. Neuroreport, 12, 285-288. http://dx.doi.org/10.1097/00001756-200102120-00021

[6] Esiri, M.M. and Wilcock, G.K. (1984) The Olfactory Bulbs in Alzheimer's Disease. Journal of Neurology, Neurosurgery \& Psychiatry, 47, 56-60. http://dx.doi.org/10.1136/jnnp.47.1.56

[7] Han, F., Shioda, N., Moriguchi, S., Qin, Z.H. and Fukunaga, K. (2008) The Vanadium (IV) Compound Rescues SeptoHippocampal Cholinergic Neurons from Neurodegeneration in Olfactory Bulbectomized Mice. Neuroscience, 151, 671-679. http://dx.doi.org/10.1016/j.neuroscience.2007.11.011

[8] Hozumi, S., Nakagawasai, O., Tan-No, K., Niijima, F., Murata, A., Arai, Y., Yasuhara, H. and Tadano, T. (2003) Characteristics of Changes in Cholinergic Function and Impairment of Learning-Memory Related Behavior Induced by Olfactory Bulbectomy. Behavioral Brain Research, 138, 9-15. http://dx.doi.org/10.1016/S0166-4328(02)00183-3

[9] Moriguchi, S., Han, F., Shioda, N., Yamamoto, Y., Nakajima, T., Nakagawasai, O., Tadano, T., Yeh, J.Z., Narahashi, T. and Fukunaga, K. (2009) Nefiracetam Activation of CaM Kinase II and Protein Kinase C Mediated by NMDA and Metabotropic Glutamate Receptors in Olfactory Bulbectomized Mice. Journal of Neurochemistry, 110, 170-181. http://dx.doi.org/10.1111/j.1471-4159.2009.06122.x

[10] Slotkin, T.A., Miller, D.B., Fumagalli, F., McCook, E.C., Zhang, J., Bissette, G. and Seidler, F.J. (1999) Modeling Geriatric Depression in Animals: Biochemical and Behavioral Effects of Olfactory Bulbectomy in Young versus Aged Rats. Journal of Pharmacology and Experimental Therapeutics, 289, 334-345.

[11] Moriguchi, S., Tanaka, T., Tagashira, H., Narahashi, T. and Fukunaga, K. (2013) Novel Nootropic Drug Sunifiram Improves Cognitive Deficits via CaM Kinase II and Protein Kinase C Activation in Olfactory Bulbectomized Mice. Behavioural Brain Research, 242, 150-157. http://dx.doi.org/10.1016/j.bbr.2012.12.054

[12] Islam, M.R., Moriguchi, S., Tagashira, H. and Fukunaga, K. (2014) Rivastigmine Restores 5-HT1A Receptor Levels in the Hippocampus of Olfactory Bulbectomized Mice. Advances in Alzheimer's Disease, 3, 128-136. http://dx.doi.org/10.4236/aad.2014.33012

[13] Hsu, H.Y. and Hsu, C.S. (1980) Commonly Used Chinese Herb Formulas with Illustrations. Oriental Healing Arts Institute (OHAI) Press, Long Beach, 343-346.

[14] Furukawa, K., Tomita, N., Uematsu, D., Okahara, K., Shimada, H., Ikeda, M., Matsui, T., Kozaki, K., Fujii, M., Ogawa, T., Umegaki, H., Urakami, K., Nomura, H., Kobayashi, N., Nakanishi, A., Washimi, Y., Yonezawa, H., Takahashi, S., Kubota, M., Wakutani, Y., Ito, D., Sasaki, T., Matsubara, E., Une, K., Ishiki, A., Yahagi, Y., Shoji, M., Sato, H., Terayama, Y., Kuzuya, M., Araki, N., Kodama, M., Yamaguchi, T. and Arai, H. (2015) Randomized Double-Blind Placebo-Controlled Multicenter Trial of Yokukansan for Neuropsychiatric Symptoms in Alzheimer's Disease. Geriatrics \& Gerontology International. 
[15] Nagao, M., Takasaki, K., Nogami, A., Hirai, Y., Moriyama, H., Uchida, N., Kubota, K., Katsurabayashi, S., Mishima, K., Nishimura, R. and Iwasaki, K. (2014) Effect of Yokukansan on Sleep Disturbance in a Rat Model of Cerebrovascular Dementia. Traditional \& Kampo Medicine, 1, 19-26.

[16] Nogami, A., Takasaki, K., Kubota, K., Yamaguchi, K., Kawasaki, C., Nakamura, K., Fujikawa, R., Uchida, N., Katsurabayashi, S., Mishima, K., Nishimura, R., Fujiwara, M. and Iwasaki, K. (2013) Effect of Yokukansan on Memory Disturbance in an Animal Model of Cerebrovascular Dementia. Journal of Traditional Medicines, 30, 164-175.

[17] Zhao, H., Ji, Z.H., Liu, C. and Yu, X.Y. (2015) Neuroprotection and Mechanisms of Atractylenolide III in Preventing Learning and Memory Impairment Induced by Chronic High-Dose Homocysteine Administration in Rats. Neuroscience, 290, 485-491. http://dx.doi.org/10.1016/j.neuroscience.2015.01.060

[18] Yabuki, Y., Shinoda, Y., Izumi, H., Ikuno, T., Shioda, N. and Fukunaga, K. (2015) Dehydroepiandrosterone Administration Improves Memory Deficits Following Transient Brain Ischemia through Sigma-1 Receptor Stimulation. Brain Research, 1622, 102-113. http://dx.doi.org/10.1016/j.brainres.2015.05.006

[19] Steru, L., Chermat, R., Thierry, B. and Simon, P. (1985) The Tail Suspension Test: A New Method for Screening Antidepressants in Mice. Psychopharmacology, 85, 367-730. http://dx.doi.org/10.1007/BF00428203

[20] Fukunaga, K., Goto, S. and Miyamoto, E. (1988) Immunohistochemical Localization of $\mathrm{Ca}^{2+} /$ Calmodulin-Dependent Protein Kinase II in Rat Brain and Various Tissues. Journal of Neurochemistry, 51, 1070-1078. http://dx.doi.org/10.1111/j.1471-4159.1988.tb03070.x

[21] Prickaerts, J., Staveren, W.C., Sik, A., Markerink-van Ittersum, M., Niewöhner, U., van der Staay, F.J., Blokland, A. and de Vente, J. (2002) Effects of Two Selective Phosphodiesterase Type 5 Inhibitors, Sildenafil and Vardenafil, on Object Recognition Memory and Hippocampal Cyclic GMP Levels in the Rat. Neuroscience, 113, 351-361. http://dx.doi.org/10.1016/S0306-4522(02)00199-9

[22] Moriguchi, S., Sakagami, H., Yabuki, Y., Sasaki, Y., Izumi, H., Zhang, C., Han, F. and Fukunaga, K. (2014) Stimulation of Sigma-1 Receptor Ameliorates Depressive-Like Behaviors in CaMKIV Null Mice. Molecular Neurobiology, 52, 1210-1222. http://dx.doi.org/10.1007/s12035-014-8923-2

[23] Moriguchi, S., Shinoda, Y., Yamamoto, Y., Sasaki, Y., Miyajima, K., Tagashira, H. and Fukunaga, K. (2013) Stimulation of the Sigma-1 Receptor by DHEA Enhances Synaptic Efficacy and Neurogenesis in the Hippocampal Dentate Gyrus of Olfactory Bulbectomized Mice. PLoS ONE, 8, e60863. http://dx.doi.org/10.1371/journal.pone.0060863

[24] Pudell, C., Vicente, B.A., Delattre, A.M., Carabelli, B., Mori, M.A., Suchecki, D., Machado, R.B., Zanata, S.M., Visentainer, J.V., de Oliveira Santos Junior, O., Lima, M.M. and Ferraz, A.C. (2014) Fish Oil Improves Anxiety-Like, Depressive-Like and Cognitive Behaviors in Olfactory Bulbectomized Rats. European Journal of Neuroscience, 39, 266-274. http://dx.doi.org/10.1111/ejn.12406

[25] Rinwa, P., Kumar, A. and Garg, S. (2013) Suppression of Neuroinflammatory and Apoptotic Signaling Cascade by Curcumin Alone in Combination with Piperine in Rat Model of Olfactory Belbectomy Induced Depression. PLoS ONE, 8, e61052. http://dx.doi.org/10.1371/journal.pone.0061052

[26] Chen, Y.J., Zheng, H.Y., Huang, X.X., Han, S.X., Zhang, D.S., Ni, J.Z. and He, X.Y. (2015) Neuroprotective Effects of Icariin on Brain Metabolism, Mitochondrial Functions, and Cognition in Triple-Transgenic Alzheimer's Disease Mice. CNS Neuroscience \& Therapeutics, 22, 63-73. http://dx.doi.org/10.1111/cns.12473

[27] Yamada, M., Hayashida, M., Zhao, Q., Shibahara, N., Tanaka, K., Miyata, T. and Matsumoto, K. (2011) Ameliorative Effects of Yokukansan on Learning and Memory Deficits in Olfactory Bulbectomized Mice. Journal of Ethnopharmacology, 135, 737-746. http://dx.doi.org/10.1016/j.jep.2011.04.010

[28] Fujiwara, H., Takayama, S., Iwasaki, K., Tabuchi, M., Yamaguchi, T., Sekiguchi, K., Ikarashi, Y., Kudo, Y., Kase, Y., Arai, H. and Yaegashi, N. (2011) Yokukansan, a Traditional Japanese Medicine, Ameliorates Memory Disturbance and Abnormal Social Interaction with Anti-Aggregation Effect of Cerebral Amyloid $\beta$ Proteins in Amyloid Precursor Protein Transgenic Mice. Neuroscience, 180, 305-313. http://dx.doi.org/10.1016/j.neuroscience.2011.01.064

[29] Giese, K.P., Fedorov, N.B., Filipkowski, R.K. and Silva, A.J. (1998) Autophosphorylation at Thr ${ }^{286}$ of the Alpha Calcium-Calmodulin Kinase II in LTP and Learning. Science, 279, 870-873. http://dx.doi.org/10.1126/science.279.5352.870

[30] Fukunaga, K., Shioda, N. and Miyamoto, E. (2009) The Function of CaM Kinase II in Synaptic Plasticity and Spine Formation. In: Lajtha, A., Ed., Handbook of Neurochemistry and Molecular Neurobiology, Neural Signaling Mechanisms, Springer, New York, 163-183. http://dx.doi.org/10.1007/978-0-387-30370-3 9

[31] Duman, R.S., Heninger, G.R. and Nestler, E.J. (1997) A Molecular and Cellular Theory of Depression. Archives of General Psychiatry, 54, 597-606. http://dx.doi.org/10.1001/archpsyc.1997.01830190015002

[32] Ghosh, A., Carnahan, J. and Greenberg, M.E. (1994) Requirement for BDNF in Activity-Dependent Survival of Cortical Neurons. Science, 263, 1618-1623. http://dx.doi.org/10.1126/science.7907431

[33] Monteggia, L.M., Barrot, M., Powell, C.M., Berton, O., Galanis, V., Gemelli, T., Meuth, S., Nagy, A., Greene, R.W. 
and Nestler, E.J. (2004) Essential Role of Brain-Derived Neurotrophic Factor in Adult Hippocampal Function. Proceedings of the National Academy of Sciences of the United States of America, 101, 10827-10832. http://dx.doi.org/10.1073/pnas.0402141101

[34] Duman, R.S. and Monteggia, L.M. (2006) A Neurotrophic Model for Stress-Related Mood Disorders. Biological Psychiatry, 59, 1116-1127. http://dx.doi.org/10.1016/j.biopsych.2006.02.013

[35] Korte, M., Carroll, P., Wolf, E., Brem, G., Thoenen, H. and Bonhoeffer, T. (1995) Hippocampal Long-Term Potentiation Is Impaired in Mice Lacking Brain-Derived Neurotrophic Factor. Proceedings of the National Academy of Sciences of the United States of America, 92, 8856-8860. http://dx.doi.org/10.1073/pnas.92.19.8856

[36] Korte, M., Staiger, V., Griesbeck, O., Thoenen, H. and Bonhoeffer, T. (1996) The Involvement of Brain-Derived Neurotrophic Factor in Hippocampal Long-Term Potentiation Revealed by Gene Targeting Experiments. Journal of Physiology-Paris, 90, 157-164. http://dx.doi.org/10.1016/S0928-4257(97)81415-5

[37] Patterson, S.L., Abel, T., Deuel, T.A., Martin, K.C., Rose, J.C. and Kandel, E.R. (1996) Recombinant BDNF Rescues Deficits in Basal Synaptic Transmission and Hippocampal LTP in BDNF Knockout Mice. Neuron, 16, 1137-1145. http://dx.doi.org/10.1016/S0896-6273(00)80140-3

[38] Phillips, H.S., Hains, J.M., Armanini, M., Laramee, G.R., Johnson, S.A. and Winslow, J.W. (1991) BDNF mRNA Is Decreased in the Hippocampus of Individuals with Alzheimer's Disease. Neuron, 7, 695-702. http://dx.doi.org/10.1016/0896-6273(91)90273-3

[39] Siegel, G.J. and Chauhan, N.B. (2000) Neurotrophic Factors in Alzheimer's and Parkinson's Disease Brain. Brain Research. Brain Research Reviews, 33, 199-227. http://dx.doi.org/10.1016/S0165-0173(00)00030-8 